\title{
MATRIK
}

Jurnal Manajemen dan Teknik Industri-Produksi

Journal homepage: http://www.journal.umg.ac.id/index.php/matriks

\section{IMPLEMENTASI TOTAL PRODUCTIVE MAINTENANCE SEBAGAI PENUNJANG PRODUKTIVITAS DENGAN MENGGUNAKAN METODE OVERALL EQUIPMENT EFFECTIVENESS}

\author{
Antoni Yohanes $^{*}$, Firman Ardiansyah Ekoanindiyo ${ }^{2}$ \\ Program Studi Teknik Industri, Fakultas Teknik, Universitas Stikubank Semarang \\ Jl. Kendeng V Bendan Ngisor, Semarang, Jawa Tengah, Indonesia \\ antoni@edu.unisbank.ac.id
}

\begin{tabular}{l}
\hline INFO ARTIKEL \\
\hline Jejak Artikel : \\
Upload artikel \\
16 Oktober 2020 \\
Revisi dari reviewer \\
17 Maret 2021 \\
Publish \\
30 Maret 2021 \\
\hline
\end{tabular}

Kata Kunci :

perawatan, overall equipment

effectiveness, six big losses

\begin{abstract}
ABSTRAK
Salah satu faktor yang harus diperhatikan untuk mempertahankan kualitas produk adalah perawatan mesin (maintenance). Berkaitan dengan hal tersebut, maka pihak pihak terkait harus mampu menemukan sistem perawatan yang baik sehingga dapat meminimasi jumlah breakdown mesin dan biaya perbaikan atau perawatan. Dalam proses produksi Tic-Tac, mesin yang sering mengalami jumlah downtime besar adalah continue frying. Tujuan dari penelitian ini adalah untuk mengetahui bagaimana kondisi maintenance dari divisi Tic-Tac dan bagaimana tingkat efektivitas serta rekomendasi yang tepat untuk meningkatkan produksivitas tersebut. Metode yang digunakan adalah overall equpment effectiveness dengan six big losses. Setelah dilakukan penelitian, rata-rata perhitungan nilai Overall equipment Effectiveness adalah $97,69 \%$. Nilai tersebut diatas standart nilai ideal overall equipment effectiveness yaitu sebesar $\geq 85 \%$.Standart nilai OEE yang bisa menjadikan goal jangka panjang adalah $85 \%$, sehingga sudah memenuhi standart. Faktor yang mempengaruhi six big losses adalah breakdown losses yaitu sebesar $85,72 \%$ dari jumlah time losses yang terjadi. Faktor-faktor yang mempengaruhi breakdown losses antara lain faktor mesin, lingkungan, metode, manusia. Dari faktor tersebut faktor mesin serta metode yang paling dominan. Untuk mengurangi hal tersebut, maka perlu adanya autonomous maintenance yang diberikan kepada operator, melakukan pelatihan bagi teknisi maintenance dengan adanya pengontrolan kemajuan ketrampilan dan kemampuan. Pengontrolan dan pengawasan operator tentang kebersihan mesin.
\end{abstract}




\section{Pendahuluan}

PT. Metta Boga adalah salah satu produsen makanan ringan yang terdepan dan paling terkenal di Indonesia yang berlokasi di jalan Raya Pati-Kudus. PT. Metta Boga telah berhasil memproduksi berbagai jenis kacang tanah, bijibijian, dan butir gandum yang saat ini dimiliki oleh produk-produk lezat dan bergizi PT. Metta Boga. Tingginya jam operasi mesin yang digunakan, maka memerlukan adanya perawatan yang tepat. Salah satu permasalahan yang dihadapi adalah tingginya tingkat downtime pada mesin yang digunakan dalam proses produksi di divisi Tic-Tac. Dalam proses pembuatan produk Tic-Tac terdapat beberapa mesin yang digunakan antara lain mesin mixer, extrooder, continues frying, ayak tiris, dan seasoning. Dari mesin-mesin tersebut, mesin yang tingkat downtime paling besar adalah mesin continues frying. Apabila terjadi kerusakan maka akan berhenti untuk dilakukan perbaikan sehingga proses produksi akan berhenti. Oleh karena itu dibutuhkan pengukuran produktivitas mesin. Menghitung dan menambah tingkat produktivitas, diperlukan pendekatan multidisipliner yang melibatkan semua usaha, kecakapan, keahlian, modal, teknologi, manajemen, dan sumbersumber yang lain secara tepadu. Salah satu pendekatan yang dapat digunakan adalah total productive maintenance (TPM). Tujuan dari penelitian ini adalah menganalisis kondisi maintenance mesin pada PT. Metta Boga divisi Tic-Tac, menghitung tingkat efektivitas mesin Continue Frying pada PT. Metta Boga divisi Tic-Tac, dan memberikan rekomendasi cara peningkatan efektivitas mesin pada PT. Metta Boga divisi Tic-Tac.

Masalah yang harus diselesaikan yaitu bagaimana kondisi maintenance pada divisi Tic-Tac saat ini, bagaimana tingkat efektifitas mesin Continue frying pada divisi Tic-Tac dan bagaimana cara untuk meningkatkan efektivitas mesin Continue Frying pada divisi Tic-Tac?
Tujuan yang ingin dicapai dari penelitian ini adalah menganalisis kondisi maintenance mesin pada divisi Tic-Tac, menghitung tingkat efektivitas mesin Continue Frying pada divisi Tic-Tac dan memberikan rekomendasi cara peningkatan efektivitas mesin pada PT. XYZ divisi Tic-Tac.

Penelitian yang dilakukan oleh Astrid Diandi Maulida, Erry Rimawan dan Muhammad Kholil (2016) yang berjudul "Analisis Productive Maintenance terhadap produktivitas kapal/armada menggunakan metode Overall Equipment Efectiveness pada PT. Global Trans Energy Internasional" dengan mempertimbangkan dari segi waktu tunggu yang dihasilkan kapal/armada beroperasi, tujuannya untukmengetahui nilai efisiensi dan efektivitas kapal/armada dengan penerapan Total Productive Maintenance menggunakan metode Overall Equipment efectiveness.

Penelitian yang dilakukan oleh Supriyadi, Gina Ramayanti dan Romi (2017) yang berjudul "Analisis Total Productive Maintenance dengan Metode Overall Equipment Effectiveness dan Fuzzy Failue Mode and Effects Analysis" yang mengambil lokasi penelitian di perusahaan pembangkit listrik, permasalahan yang dihadapi yaitu tingkat produktivits mesin Ash Handling yaitu mesin yang berfungsi untuk menyalurkan limbah pembuangan sisa hasil proses pembakaran batu bara pada broiler.

Penelitian yang dilakukan oleh Dyah Ika Rinawati dan Nadia Cynthia Dewi (2014) yang berjudul "Analisis penerapan Total Productive Maintenance (TPM) menggunakan Overall Equipent Efectiveness (OEE) dan Six Big Losses pada mesin Cavitec di PT. Essentra Surabaya" yang bertujuan untuk mengukur nilai efektifitas peralatan, mencari akar penyebab masalah dan memberikan usulan perbaikan. Penelitian tersebut dilakukan pada mesin dual (combiner) yaitu mesin Cavitec VD-02 yang memiliki tingkat breakdown yang tinggi. Mesin 
ini mengkombinasikan base rod dengan segmen butikan karbon.

Penelitian yang dilakukan oleh Rahmad, Pratikto, dan Slamet Wahyudi (2012) yang berjudul "Penerapan Overall Equipment Effectiveness (OEE) dalam implementasi Total Productive Maintenance (TPM)" yang mengambil lokas penelitian di pabrik gula PT. "Y", dimana permasalahan yang dihadapi adalah kerusakan mesin yang sering terjadi pada unit mesin giling I yang menunjukkan bahwa ada masalah yang terjadi pada stasiun penggilingan.

Penelitian yang dilakukan oleh Anwar, Syukriah, dan Muslem (2016) yang berjudul "Analisis Overall Equipment Effectiveness (OEE) dalam meminimalisir six big losses pada mesin produksi di UD. Hidup Baru" yang mengambil lokasi penelitian di UD. Hidup Baru yaitu industri yang bergerak dalam produksi minyak kelapa, permasalahan yang dihadapi antara lain tingkat kerusakan mesin yang cukup tinggi (breakdown). Pada penelitian ini peneliti berfokus pada mesin pres 2 yang berfungsi sebagai finishing pengepresan minyak kelapa.

\section{Metode Penelitian}

Objek dari penelitian ini adalah data harian maintenance dan kapasitas produksi pada periode Oktober 2019 sampai Mei 2020 yang didapatkan dari bagian maintenance dan quality control divisi Tic-Tac PT. Metta Boga yang berada di jalan raya Pati-Kudus-Jawa TengahIndonesia.

Menghitung elemen-elemen Total Productive Maintenance antara lain:
a. Avaibility
b. Performance Rate
c. Quality Rate
d. Overall Equipment Evectiveness

Pengukuran OEE didasarkan pada pengukuran availability ratio, performance ratio, dan quality ratio. Availability merupakan rasio dari operation time, dengan mengeliminasi downtime peralatan, terhadap loading time. Performance ratio adalah rasio yang menggambarkan kemampuan peralatan dalam menghasilkan produk yang merupakan hasil dari operating speed rate dan net operating rate. Operating speed rate berdasarkan perbedaan antara kecepatan ideal dan kecepatan operasi aktual. Net operating rate melakukan pengukuran suatu kecepatan dalam periode tertentu (Suhendra \& Betrianis, 2005). Quality ratio adalah rasio yang menggambarkan kemampuan mesin dalam menghasilkan produk sesuai dengan spesifikasi yang telah ditetapkan.

e. Six Big Losses

1. Breakdown Loss,

2. Set-up and Adjustment Loss,

3. Idling and minor stoppage losses,

4. Reduced Speed losses,

5. Quality defect and required losses,

6. Yield/scrap Losses,

f. Pembuatan diagram pareto

g. Pembuatan diagram sebab akibat

h. Kesimpulan

\section{Hasil dan Pembahasan}

Data Running Time

Running time adalah waktu keseluruhan yang menunjukkan jumlah jam kerja yang digunakan dalam proses produksi. Downtime adalah waktu dimana mesin berhenti produksi dikarenakan keadaan yang tidak terduga. Loading time adalah waktu bersih yang tersedia dalam proses produksi. Operation time adalah total waktu proses produksi yang efektif. 
Tabel 1. Data Operation Time

\begin{tabular}{|c|c|c|c|}
\hline Periode & $\begin{array}{c}\text { Loading } \\
\text { Time } \\
\text { (menit) }\end{array}$ & $\begin{array}{c}\text { Total } \\
\text { Downtime } \\
\text { (menit) }\end{array}$ & $\begin{array}{c}\text { Operation } \\
\text { Time } \\
\text { (menit) }\end{array}$ \\
\hline Oktober & $35.037,00$ & $6.168,00$ & $28.869,00$ \\
November & $38.242,80$ & $2.031,92$ & $36.210,88$ \\
Desember & $39.180,00$ & $1.920,00$ & $37.260,00$ \\
Januari & $36.802,80$ & $4.095,00$ & $32.707,80$ \\
Februari & $32.613,00$ & $2.970,00$ & $29.643,00$ \\
Maret & $39.675,00$ & $2.070,00$ & $37.605,00$ \\
April & $35.940,00$ & $3.780,00$ & $32.160,00$ \\
Mei & $39.081,00$ & $3.060,00$ & $36.021,00$ \\
\hline
\end{tabular}

Data Reject

Data Reject adalah data yang menunjukan produk yang cacat. Berikut adalah data reject periode Oktober 2019 sampai Mei 2020.

Tabel 2. Data Reject

\begin{tabular}{|l|l|l|}
\hline Periode & $\begin{array}{l}\text { jumlah produksi } \\
(\mathrm{kg})\end{array}$ & $\begin{array}{l}\text { Reject } \\
(\mathrm{kg})\end{array}$ \\
\hline Oktober & $992.181,25$ & 935,80 \\
November & $980.437,50$ & 661,30 \\
Desember & $947.632,50$ & 752,50 \\
Januari & $1.175 .445,00$ & $1.475,46$ \\
Februari & $1.020 .647,50$ & 530,86 \\
Maret & $1.090 .125,00$ & 541,35 \\
April & $1.029 .445,00$ & 384,48 \\
Mei & $1.096 .929,00$ & 811,28 \\
\hline total & $8.332 .842,75$ & $6.093,03$ \\
\hline
\end{tabular}

Perhitungan Nilai Avaibility Rate

Avaibility adalah tingkat rasio operation time terhadap loading time.

Tabel 3. Data Perhitungan Avaibility Rate

\begin{tabular}{|c|c|c|c|c|}
\hline Periode & $\begin{array}{c}\text { Loading } \\
\text { Time } \\
\text { (menit) }\end{array}$ & $\begin{array}{c}\text { Total } \\
\text { Downtime } \\
\text { (menit) }\end{array}$ & $\begin{array}{c}\text { Operation } \\
\text { Time } \\
\text { (menit) }\end{array}$ & $\begin{array}{c}\text { Avaibility } \\
\text { rate (\%) }\end{array}$ \\
\hline Oktober & $35.037,00$ & $6.168,00$ & $28.869,00$ & $82,40 \%$ \\
November & $38.242,80$ & $2.031,92$ & $36.210,88$ & $94,69 \%$ \\
Desember & $39.180,00$ & $1.920,00$ & $37.260,00$ & $95,10 \%$ \\
Januari & $36.802,80$ & $4.095,00$ & $32.707,80$ & $88,87 \%$ \\
Februari & $32.613,00$ & $2.970,00$ & $29.643,00$ & $90,89 \%$ \\
Maret & $39.675,00$ & $2.070,00$ & $37.605,00$ & $94,78 \%$ \\
April & $35.940,00$ & $3.780,00$ & $32.160,00$ & $89,48 \%$ \\
Mei & $39.081,00$ & $3.060,00$ & $36.021,00$ & $92,17 \%$ \\
\hline total & $296.571,60$ & $26.094,92$ & $270.476,68$ & $91,05 \%$ \\
\hline
\end{tabular}

Perhitungan Nilai Performance rate

Performance Rate adalah tingkat rasio kualitas produk yang dihasilkan dikalikan dengan waktu siklus idealnya terhadap waktu yang tersedia untuk melakukan proses produksi (operation time). Perhitungan performance rate dimulai dengan perhitungan ideal cycel time. Ideal cycle time merupakan waktu siklus ideal mesin dalam melakukan proses produksi. Untuk menghitung ideal cycle time maka perlu diperhatikan persentase jam kerja terhadap delay. Dimana delay sama dengan total downtime.

Tabel 4. Perhitungan Performance Rate

\begin{tabular}{|c|c|c|c|c|}
\hline Periode & $\begin{array}{c}\text { jumlah } \\
\text { produksi }\end{array}$ & $\begin{array}{c}\text { ideal } \\
\text { cycle } \\
\text { time }\end{array}$ & $\begin{array}{c}\text { operation } \\
\text { time } \\
\text { (menit) }\end{array}$ & $\begin{array}{c}\text { performance } \\
\text { rate (\%) }\end{array}$ \\
\hline Oktober & $992.181,25$ & 0,03 & $28.869,00$ & $103,11 \%$ \\
November & $980.437,50$ & 0,04 & $36.210,88$ & $108,30 \%$ \\
Desember & $947.632,50$ & 0,04 & $37.260,00$ & $101,73 \%$ \\
Januari & $1.175 .445,00$ & 0,03 & $32.707,80$ & $107,81 \%$ \\
Februari & $1.020 .647,50$ & 0,03 & $29.643,00$ & $103,29 \%$ \\
Maret & $1.090 .125,00$ & 0,04 & $37.605,00$ & $115,96 \%$ \\
April & $1.029 .445,00$ & 0,03 & $32.160,00$ & $96,03 \%$ \\
Mei & $1.096 .929,00$ & 0,04 & $36.021,00$ & $121,81 \%$ \\
\hline
\end{tabular}

Quality rate

Rate of quality adalah tingkat rasio produk yang baik, sesuai dengan spesifikasi kualitas produk yang telah ditentukan terhadap jumlah produk yang di proses.

Tabel 5. Data perhitungan Rate of Quality

\begin{tabular}{|c|c|c|c|}
\hline Periode & $\begin{array}{c}\text { jumlah } \\
\text { produksi } \\
(\mathrm{kg})\end{array}$ & Reject (kg) & $\begin{array}{c}\text { rate of } \\
\text { Quality } \\
(\%)\end{array}$ \\
\hline Oktober & $992.181,25$ & 935,80 & $99,91 \%$ \\
November & $980.437,50$ & 661,30 & $99,93 \%$ \\
Desember & $947.632,50$ & 752,50 & $99,92 \%$ \\
Januari & $1.175 .445,00$ & $1.475,46$ & $99,87 \%$ \\
Februari & $1.020 .647,50$ & 530,86 & $99,95 \%$ \\
Maret & $1.090 .125,00$ & 541,35 & $99,95 \%$ \\
April & $1.029 .445,00$ & 384,48 & $99,96 \%$ \\
Mei & $1.096 .929,00$ & 811,28 & $99,93 \%$ \\
\hline Total & $8.332 .842,75$ & $6.093,03$ & $99,93 \%$ \\
\hline
\end{tabular}


MATRIK : Jurnal Manajemen \& Teknik Industri - Produksi Volume XXI, No.2, Maret 2021, Halaman 185-194

Perhitungan Overall Equipment Effectiveness (OEE)

Overall equipment effectiveness adalah pengukuran dalam Total Productive Maintenance yang digunakan untuk menghitung sebuah peralatan atau line produksi secara stabil.

Tabel 6. Data perhitungan Perhitungan Overall

\begin{tabular}{|c|c|c|c|c|}
\multicolumn{5}{c|}{ Equipment Effectiveness } \\
\hline periode & $\begin{array}{c}\text { availability } \\
\text { rate }\end{array}$ & $\begin{array}{c}\text { performance } \\
\text { rate }\end{array}$ & $\begin{array}{c}\text { overall } \\
\text { rate of } \\
\text { quality } \\
\text { equipment } \\
\text { effectivenes } \\
\text { s (\%) }\end{array}$ \\
\hline Oktober & 0,8240 & 1,0311 & 0,9991 & $84,89 \%$ \\
November & 0,9469 & 1,083 & 0,9993 & $102,48 \%$ \\
Desember & 0,951 & 1,0173 & 0,9992 & $96,67 \%$ \\
Januari & 0,8887 & 1,0781 & 0,9987 & $95,69 \%$ \\
Februari & 0,9089 & 1,0329 & 0,9995 & $93,83 \%$ \\
Maret & 0,9478 & 1,1596 & 0,9995 & $109,85 \%$ \\
April & 0,8948 & 0,9603 & 0,9996 & $85,89 \%$ \\
Mei & 0,9217 & 1,2181 & 0,9993 & $112,19 \%$ \\
\hline Average & 0,9105 & 1,0726 & 0,999275 & $97,69 \%$ \\
\hline
\end{tabular}

Six Big Losses

Dari perhitungan overall equipment effectiveness untuk meningkatkan efektivitas, maka sebagai pendukung dilakukan perhitungan six big losses untuk mempermudah menganalisa akar penyebab masalah yang paling dominan mengakibatkan efektivitas tidak optimal.

\section{Equipment Failur (Breakdown)}

Kegagalan mesin dalam melakukan proses (equipment failed) atau kerusakan (breakdown) yang tiba-tiba dan tidak diharapkan terjadi adalah penyebab kerugian yang sangat terlihat jelas.
p-ISSN: 1693-5128, e-ISSN : 2621-8933

doi: 10.350587/Matrik v21.i2.1973

Tabel 7. Data perhitungan Equipment Failur losses breakdown

\begin{tabular}{|c|c|c|c|}
\hline periode & $\begin{array}{c}\text { total waktu } \\
\text { kerusakan } \\
\text { (menit) }\end{array}$ & $\begin{array}{c}\text { loading } \\
\text { time (menit) }\end{array}$ & $\begin{array}{c}\text { breakdown } \\
\text { losses (\%) }\end{array}$ \\
\hline Oktober & $6.168,00$ & $35.037,00$ & $17,60 \%$ \\
November & $2.031,92$ & $38.242,80$ & $5,31 \%$ \\
Desember & $1.920,00$ & $39.180,00$ & $4,90 \%$ \\
Januari & $4.095,00$ & $36.802,80$ & $11,13 \%$ \\
Februari & $2.970,00$ & $32.613,00$ & $9,11 \%$ \\
Maret & $2.070,00$ & $39.675,00$ & $5,22 \%$ \\
April & $3.780,00$ & $35.940,00$ & $10,52 \%$ \\
Mei & $3.060,00$ & $39.081,00$ & $7,83 \%$ \\
\hline
\end{tabular}

Set Up and Adjustment Losses

Kerusakan pada mesin secara keseluruhan akan mengakibatkan mesin tersebut harus berhenti terlebih dahulu. Sebelum mesin difungsikan kembali, akan dilakukan penyesuaian terhadap fungsi mesin yang dinamakan dengan waktu setup and adjustment mesin.

Tabel 8. Data perhitungan Set Up and Adjustment Losses

\begin{tabular}{|c|c|c|c|}
\hline periode & $\begin{array}{c}\text { set up } \\
\text { (menit) }\end{array}$ & $\begin{array}{c}\text { loading } \\
\text { time (menit) }\end{array}$ & $\begin{array}{c}\text { set up \& } \\
\text { adjustment } \\
\text { losses (\%) }\end{array}$ \\
\hline Oktober & 300 & $35.037,00$ & $0,86 \%$ \\
November & 100 & $38.242,80$ & $0,26 \%$ \\
Desember & 150 & $39.180,00$ & $0,38 \%$ \\
Januari & 550 & $36.802,80$ & $1,49 \%$ \\
Februari & 400 & $32.613,00$ & $1,23 \%$ \\
Maret & 250 & $39.675,00$ & $0,63 \%$ \\
April & 550 & $35.940,00$ & $1,53 \%$ \\
Mei & 650 & $39.081,00$ & $1,66 \%$ \\
\hline
\end{tabular}

\section{Reduced Speed Losses}

Reduced speed losses adalah kerugian yang diakibatkan oleh mesin yang tidak bisa bekerja secara optimal dan kecepatan mesin actual lebih kecil daripada kecepatan normal. 
Tabel 9. Data perhitungan Reduced Speed Losses

\begin{tabular}{|c|c|c|c|c|c|c}
\hline Periode & $\begin{array}{c}\text { Loading } \\
\text { Time } \\
\text { (menit) }\end{array}$ & $\begin{array}{c}\text { ideal } \\
\text { cycle } \\
\text { time } \\
\text { (menit) }\end{array}$ & $\begin{array}{c}\text { total produksi } \\
(\mathrm{kg})\end{array}$ & $\begin{array}{c}\text { ideal } \\
\text { productive } \\
\text { time } \\
\text { (menit) }\end{array}$ & $\begin{array}{c}\text { operation } \\
\text { time } \\
\text { (menit) }\end{array}$ & $\begin{array}{c}\text { Losses } \\
(\%)\end{array}$ \\
\hline Oktober & $35.037,00$ & 0,03 & $992.181,25$ & 29765,44 & $28.869,00$ & $-2,56 \%$ \\
November & $38.242,80$ & 0,04 & $980.437,50$ & 39217,50 & $36.210,88$ & $-7,86 \%$ \\
Desember & $39.180,00$ & 0,04 & $947.632,50$ & 37905,30 & $37.260,00$ & $-1,65 \%$ \\
Januari & $36.802,80$ & 0,03 & $1.175 .445,00$ & 35263,35 & $32.707,80$ & $-6,94 \%$ \\
Februari & $32.613,00$ & 0,03 & $1.020 .647,50$ & 30619,43 & $29.643,00$ & $-2,99 \%$ \\
Maret & $39.675,00$ & 0,03 & $1.090 .125,00$ & 32703,75 & $37.605,00$ & $12,35 \%$ \\
April & $35.940,00$ & 0,03 & $1.029 .445,00$ & 30883,35 & $32.160,00$ & $3,55 \%$ \\
Mei & $39.081,00$ & 0,03 & $1.096 .929,00$ & 32907,87 & $36.021,00$ & $7,97 \%$ \\
\hline
\end{tabular}

Defect Losses

Defect losses merupakan kerugian yang dikarenakan adanya produk yang tidak sesuai dengan spesifikasi atau produk cacat sehingga perlu dikerjakan ulang atau dihancukan.

Tabel 10. Data perhitungan Defect Losses

\begin{tabular}{|c|c|c|c|c|}
\hline Periode & $\begin{array}{c}\text { loading } \\
\text { time } \\
\text { (menit) }\end{array}$ & $\begin{array}{c}\text { ideal } \\
\text { cycle } \\
\text { time } \\
\text { (menit) }\end{array}$ & $\begin{array}{c}\text { defect } \\
\text { amount } \\
(\mathrm{kg})\end{array}$ & $\begin{array}{c}\text { Losses } \\
(\mathrm{kg})\end{array}$ \\
\hline Oktober & $35.037,00$ & 0,03 & 935,80 & $0,08 \%$ \\
November & $38.242,80$ & 0,04 & 661,30 & $0,07 \%$ \\
Desember & $39.180,00$ & 0,04 & 752,50 & $0,08 \%$ \\
Januari & $36.802,80$ & 0,03 & $1.475,46$ & $0,12 \%$ \\
Februari & $32.613,00$ & 0,03 & 530,86 & $0,05 \%$ \\
Maret & $39.675,00$ & 0,03 & 541,35 & $0,04 \%$ \\
April & $35.940,00$ & 0,03 & 384,48 & $0,03 \%$ \\
Mei & $39.081,00$ & 0,03 & 811,28 & $0,06 \%$ \\
\hline
\end{tabular}

Diagram Pareto

Melihat lebih jauh pengaruh six big losses terhadap efectivitas mesin continue frying. Maka dilakukan perhitungan persentase dari time losses untuk masing-masing faktor dalam six big losses.
Tabel 11. Hasil Perhitungan persentase time loss pada six big losses

\begin{tabular}{|c|c|c|c|}
\hline six big losses & $\begin{array}{l}\text { time losses } \\
\text { (menit) }\end{array}$ & $\begin{array}{c}\text { persentase } \\
(\%)\end{array}$ & $\begin{array}{c}\text { Persentase } \\
\text { Komulatif } \\
(\%)\end{array}$ \\
\hline $\begin{array}{c}\text { Breakdown } \\
\text { Losses }\end{array}$ & $26.096,19$ & $85,72 \%$ & $85,72 \%$ \\
\hline $\begin{array}{c}\text { Set up \& } \\
\text { Adjusment } \\
\text { Losses }\end{array}$ & $2.938,55$ & $9,65 \%$ & $95,37 \%$ \\
\hline $\begin{array}{c}\text { Idling \& Minor } \\
\text { Stoppages } \\
\text { Losses }\end{array}$ & 0,00 & $0,00 \%$ & $95,37 \%$ \\
\hline $\begin{array}{c}\text { Reduced } \\
\text { Speed Losses }\end{array}$ & $1.211,94$ & $3,98 \%$ & $99,35 \%$ \\
\hline $\begin{array}{c}\text { Quality Defect } \\
\text { and Required } \\
\text { Losses }\end{array}$ & 196,71 & $0,65 \%$ & $100,00 \%$ \\
\hline Yeild Losses & 0,00 & $0,00 \%$ & $100,00 \%$ \\
\hline Total & $30.443,39$ & $100,00 \%$ & \\
\hline
\end{tabular}

\section{DIAGRAM PARETO}

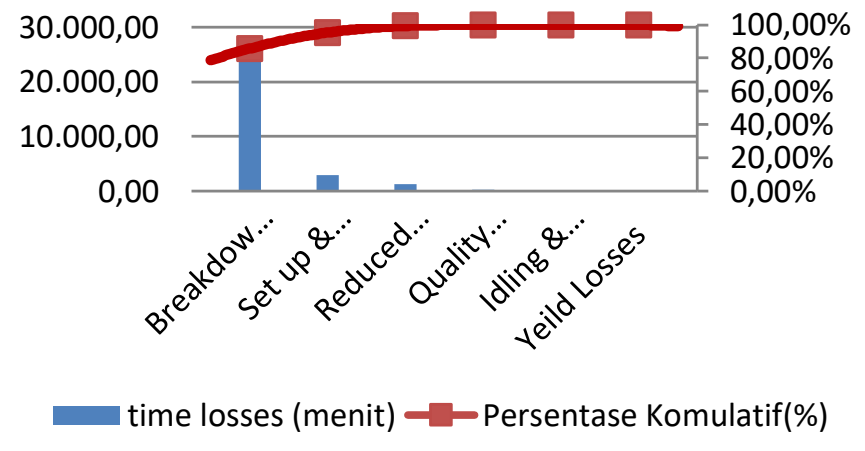

Gambar 1. Diagram Pareto

Diagram pareto diatas, dapat diketahui bahwa kerugian terbesar adalah breakdown losses dengan nilai $85,72 \%$ dan set-up and adjusment losses dengan nilai $9,65 \%$. Breakdown losses disebabkan karena kegagalan mesin dalam melakukan proses (equipment failed) atau kerusakan (breakdown) yang tibatiba dan tidak diharapkan terjadi. Sedangkan set-up and adjustment losses adalah penyesuaian kembali fungsi mesin setelah mesin berhenti beroperasi.

\section{Analisis Avaibility Rate}

Nilai avaibility tertinggi adalah pada bulan Desember yaitu sebesar 95,10\%. Pada bulan tersebut terjadi downtime selama 1.920 menit. Nilai paling rendah terjadi pada bulan Oktober 
dengan nilai $82,40 \%$. Pada bulan Oktober memiliki tingkat downtime paling besar yaitu 6.168 menit. Namun selama periode Oktober 2019 sampai Mei 2020 masih termasuk dalam kategori yang baik karena nilai avaibility lebih dari $90 \%$. Nilai rata-rata avaibility pada periode tersebut adalah $91,05 \%$.

\section{Analisis Performance Rate}

Performance rate mempertimbangkan faktor yang menyebabkan berkurangnya kecepatan produksi dari kecepatan sebenarnya yang dapat dilakukan oleh mesin tersebut. Standart untuk nilai performance rate adalah 95\%. Nilai performance rate paling tinggi terjadi pada bulan Mei dengan nilai performance rate sebesar $122 \%$. Nilai ini terjadi karena kecepatan produksi tic-tac pada bulan tersebut melebihi dari yang direncanakan. Sedangkan nilai terendah terjadi pada bulan April dengan nilai performance rate sebesar $96 \%$. Nilai rendah tersebut terjadi karena pada bulan April mesin produksi sering berenti sehingga dapat mempengaruhi performance dari mesin tersebut

\section{Analisis Quality of Rate}

Quality rate merupakan perbandingan antara produk yang lolos quality control dengan total produksi. Pada perusahaan ini, produk yang tidak lolos quality control disebut dengan reject. Produk reject tersebut selanjutnya akan dibuang. Standart internasional untuk quality of rate adalah $99,9 \%$.

Nilai quality rate paling tinggi adalah bulan April yaitu dengan nilai 99,96\%. Pada bulan tersebut, produk yang dihasilkan sebagian besar lolos quality control. Jumlah produk yang dihasilkan pada bulan April adalah 1.029.445 $\mathrm{kg}$ dengan jumlah reject sebesar $384,48 \mathrm{~kg}$. Kemudian nilai quality rate paling rendah terjadi pada bulan Januari sebesar 99,87\% dengan jumlah produksi $1.175 .445 \mathrm{~kg}$ dengan jumlah reject sebesar $1.475,46 \mathrm{~kg}$. Namun, selama 8 bulan tersebut masih termasuk dalam kategori yang baik karena nilai rate of quality lebih dari 99,9\%.

\section{Analisis Overall Equipment Effectiveness}

Nilai Overall Equipment Effectiveness yang tertinggi terjadi pada bulan Maret dan Mei. Pada bulan Maret 109,85\% dan pada bulan Mei sebesar $112,19 \%$. Standart nilai OEE yang bisa menjadikan goal jangka panjang adalah $85 \%$, sehingga pada bulan tersebut sudah memenuhi standart. Sedangkan nilai overall Equipment Effectiveness terendah terjadi pada bulan Oktober yaitu sebesar 84,89\%, kemudian diikuti bulan April sebesar $85,89 \%$, bulan Februari 93,83\%, bulan Januari 95,69\%, bulan Desember $96,67 \%$, dan bulan November sebesar $102,48 \%$.

\section{Analisis Six Big Losses}

Kerugian terbesar adalah breakdown losses dengan nilai $85,72 \%$ dan set-up and adjusment losses dengan nilai 9,65\%. Breakdown losses disebabkan karena kegagalan mesin dalam melakukan proses (equipment failed) atau kerusakan (breakdown) yang tiba-tiba dan tidak diharapkan terjadi. Sedangkan set-up and adjustment losses adalah penyesuaian kembali fungsi mesin setelah mesin berhenti beroperasi.

Analisis Diagram Sebab-Akibat

Agar perbaikan dapat segera dilakukan, maka analisis terhadap faktor-faktor six big losses yang mengakibatkan rendahnya efektivitas mesin dalam perhitungan Overall Equipment Effectiveness dilakukan dengan menggunakan diagram sebab akibat.

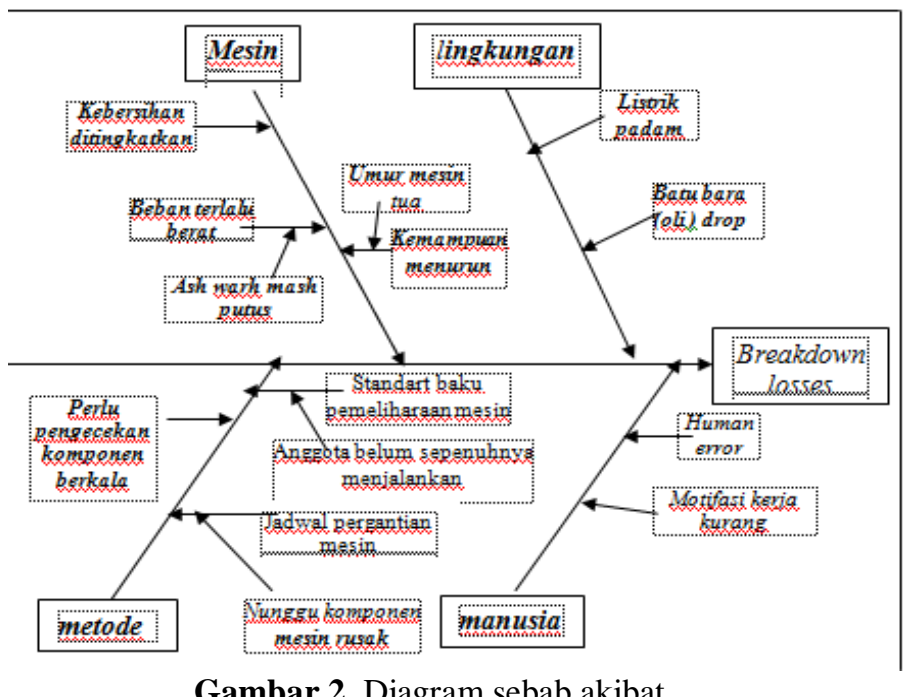

Gambar 2. Diagram sebab akibat 
Dari gambar diatas dapat diketahui bahwa terdapat 4 katagori penyebab tingginya nilai Breakdown losses, yaitu sebagai berikut:

\section{Manusia}

a. Motifasi kerja masih kurang, adanya pemberian penghargaan atas prestasi yang telah didapat.

b. Pergerakan keluar masuk karyawan saat istirahat harus ditingkatkan, karena pada karyawan laki-laki tidak ada buku absen pegawai sehingga keluar dan mulai bekerja lagi tidak terkontrol.

c. Adanya human error, contohnya kelalaian operator saat mengecek pengatur oli input, karena sering pengatur otomatis oli tidak berfungsi.

2. Metode

Metode maintenance yang menggunakan metode periodic maintenance. Metode yang digunakan oleh bagian maintenance masih bisa ditingkatkan kembali, dikarenakan ada beberapa staff maintenance kurang menjalankan proses maintenance dengan standart baku pemeliharaan mesin.

3. Mesin

Kerusakan mesin yang sering terjadi antara lain:

a. Beban terlalu berat sehingga mengakibatkan ash warh mash putus.

b. Suhu yang tidak seimbang antara oli dan minyak membuat kadar air naik sehingga mempengaruhi tingkat kerenyahan produk.

c. Pompa sirkulasi bocor dikarenakan penyumbatan sirkulasi yang mengakibatkan minyak tumpah.

d. Seringnya baut lepas

e. Faktor mesin tua, sehingga berkurangnya kemampuan kerja mesin.

f. Operator saat melakukan pengurasan minyak tidak dilakukannya juga pembersihan pipa-pipa sirkulasi sehingga mengalami sumbatan dan menghambat proses produksi.
4. Lingkungan

Faktor lingkungan juga dapat mempengaruhi tingkat breakdown losses, suhu ruangan, kondisi batu bara, serta listrik. Suhu ruangan di dalam pabrik cukup membuat operator serta karyawan lainnya kurang nyaman salama bekerja. Kondisi batu bara yang drop juga dapat mempengaruhi tingkat produktivitas, selain itu pemadaman listrik juga mempengaruhi kinerja proses produksi karena ketika terjadi mati listrik membutuhkan waktu untuk mengganti ke genset.

Usulan pemecahan Masalah

Setelah dilakukannya analisa dari hasil perhitungan dapat diketahui bahwa losses terbesar yang mengakibatkan rendahnya nilai Overall Equipment Effectiveness adalah breakdown losses. Untuk meningkatkan nilai Overall Equipment Effectiveness maka perusahaan harus mengurangi losses yang terjadi. Adapun usulan perbaikan untuk mengurangi permasalahan tersebut antara lain sebagai berikut:

1. Operator sangat berperan dalam proses produksi. Perusahaan sebaiknya memberikan penghargaan kepada karyawan yang berprestasi, peningkatan kemampuan (skill).

2. Memperkecil human error dengan menekankan standart operational prosedur kepada karyawan.

3. Adanya buku pencatat pergerakan karyawan keluar masuk ruang produksi, karena sering terjadinya keterlambatan masuk setelah istirahat khusus karyawan laki-laki.

4. Perlu adanya inspeksi peralatan mesin atau komponen mesin yang hampir aus.

5. Adanya jadwal pergantian komponen.

6. Kebersihan mesin yang perlu ditingkatkan lagi.

7. Menyiapkan checklist autonomous maintenance setiap kali dilakukan pergantian shift. 
8. Menyiapkan persediaan alat dan bahan untuk mlakukan autonomous maintenance.

9. Para staff maintenance harus berpedoman pada standart baku pemeliharaan mesin sebagai acuan.

10. Adanya evaluasi kerusakan mesin agar kerusakan tidak terulang kembali.

11. Adanya automatic sinkron genset, sehingga ketika pemadaman listrik maka secara otomatis sumber daya listrik masih menyala.

12. Adanya sinyal alarm untuk peringatan ketika operator membuka kran oli.

13. Perlunya peremajaan mesin.

14. Adanya automatic reducer untuk mengurangi beban berlebih, sehingga beban yang masuk ke continue frying tetap stabil.

15. Adanya control dan pengawasan terhadap operator saat melakukan pengurasan mesin sehingga kondisi mesin tetap bersih dan tidak ada sumbatan-sumbatan.

\section{Kesimpulan dan Saran}

Berdasarkan hasil analisa dari penelitian yang telah dilakukan, maka dapat diambil kesimpulan sebagai berikut:

1. Tingkat efektifitas mesin Continue frying pada divisi Tic-Tac Rata-rata perhitungan nilai Overall equipment Effectiveness adalah $97,69 \%$. Nilai tersebut diatas standart nilai ideal overall equipment effectiveness yaitu sebesar $\geq 85 \%$.

2. Kerugian paling besar dari persentase six big losses adalah breakdown losses, dengan persentase sebesar $85,72 \%$ dari jumlah time losses yang terjadi. Faktorfaktor yang mempengaruhi breakdown losses antara lain faktor mesin, lingkungan, metode, manusia. Dari faktor tersebut faktor mesin serta metode yang paling dominan.

\section{Saran}

1. Mengurangi breakdown losses, maka perlu adanya autonomous maintenance yang diberikan kepada operator.

2.Melakukan pelatihan bagi teknisi maintenance dengan adanya pengontrolan kemajuan ketrampilan dan kemampuan.

3.Pengontrolan dan pengawasan operator tentang kebersihan mesin.

\section{Daftar Pustaka}

[1]. Anwar., et. al. 2016. Analisis Overall Equpment effectiveness (OEE) dalam Meminimalisir Six Big Losses pada Mesin Produksi di UD. Hidup Baru. Industrial Engineering Journal. Vol. 5 No. 2 : 52-57.

[2]. Arifianto, A. 2018. Penerapan Total Productive Maintenance (TPM) Dengan Menggunakan Metode Overall Equipment Effectiveness. Skripsi. Fakultas Teknologi Industri Universitas Islam Indonesia, Yogyakarta.

[3]. Astrid D., et. Al. 2016 "Analisis Productive Maintenance terhadap produktivitas kapal/armada menggunakan metode Overall Equipment Efectiveness pada PT. Global Trans Energy Internasional"

[4]. Diandra, A. M., et. al. 2016. Analisis Total Productive Maintenance Terhadap Produktivitas Kapal/Armada Menggunakan Metode Overall Equipment Effectiveness pada PT. Global Trans Energy International. Jurnal of industrial engineering and management systems. Vol.9, No. 1 : 1-18.

[5]. Gaspersz, Vincent, "Statical Process Control: Penerapan Teknik-teknik Statistika Dalam Manajemen Bisnis Total", Edisi 1, Jakarta: PT. Gramedia Pustaka Utama, 1998.

[6]. Ika, D. R., Cynthia. N. D. 2014. Analisis Penerapan Total Productive Maintenance Menggunakan Overall Equipment Effectiveness dan Six Big Losses pada 
Mesin cavitec di PT. Essentra Surabaya. Prosiding SNATIF ke-1 : 21-26.

[7]. Kusnadi, E. Tentang Overall Equipment Effectiveness. Retrieved February 24, 2018.

From

https://eriskusnadi.wordpress.com/2011/0

9/24/tentang-overall-equipment-

effectiveness/

[8]. Ngelamunin.blogspot.co.id. Overall Equpment Effectiveness (OEE). Retrieved April 9, 2018. From http://ngelamunin.blogspot.co.id/2011/08/ overall-equipment-effectivenessoee.html?m=1

[9]. Process Untuk Mengurangi Lead Time Process Perawatan Engine (STUDI KASUS PT.GMF AEROASIA). Jurnal Optimasi Sistem Industri, Vol. 14 No. 2, Oktober 2015:299-309

[10].Pasaribu, M. Pengertian, Jenis, Dan Tujuan Maintenance. Retrieved July 30, 2018. From http://googleweblight.com/2016/12/penge rtian-jenis-dan-tujuanmaintenance.html?m\%3D1\&hl=id-ID

[11].Pyzdek,T. and P. Keller, 2013, The Hanbook For Quality Management A Complete Guide For Operational Excellent, McGraww-Hill, New York.

[12].Putrawan, A. Sistem Perawatan. Retrieved February 23, 2018. From http://googleweblight.com/?lite_url=http:/ /andreasputrawan.blogspot.com/2010/02/s istem-

perawatan_16.html?m\%3D1\&ei=4t1RLW Ky\&lc=id-

ID\&s=1\&m=814\&host=www.google.co.i d\&ts=1519387648\&sig=AOyes_S0feFxE9ovKFpXjs8X4INHxC3FQ

[13].Rahmad., Praktikto., Wahyudi, S. 2012. Penerapan Overall Equipment Effectiveness (OEE) dalam Implementasi Total Productive Maintenance (TPM) (Studi Kasus di Pabrik Gula PT."Y"). Jurnal Rekayasa Mesin. Vol.3 No.3 : 431437.
[14].Singh, H. R., Jayaswal, P. 2012. A Total Productive Maintenance Approach To Improve Overall Equipment Effeciency. International journal of modern engineering research. Vol.2,issue6 : 43834386.

[15].Sepsarianto, Rizky. 2013. Analisis Masalah 7 Tools. URL:http://www.scribd.com/doc/1893221 19/Analisis-Masalah-7-Tools. Diakses tanggal 2 Agustus 2018.

[16].Supriyadi., et. al. 2017. Analisis Total Productive Maintenance dengan Metode Overall equipment Effectiveness dan Fuzzy Failure Mode and Effects Analysis. Sinergi. Vol.21, No. 3 : 165-172. 